
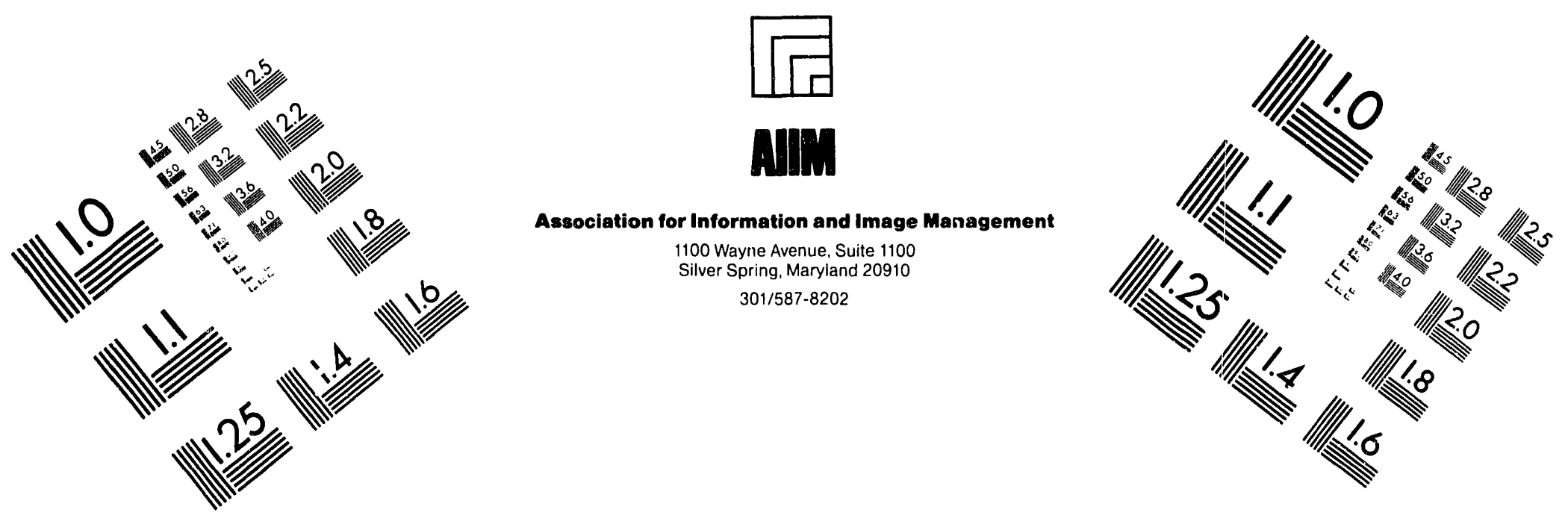

\title{
Centimeter
}

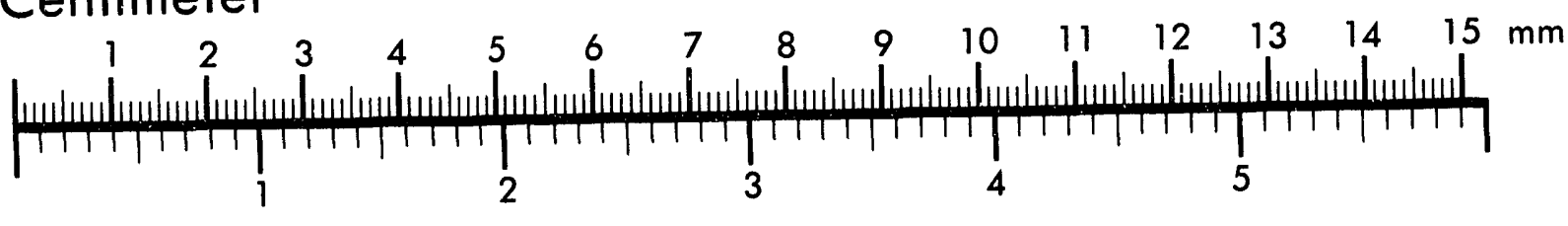
Inches
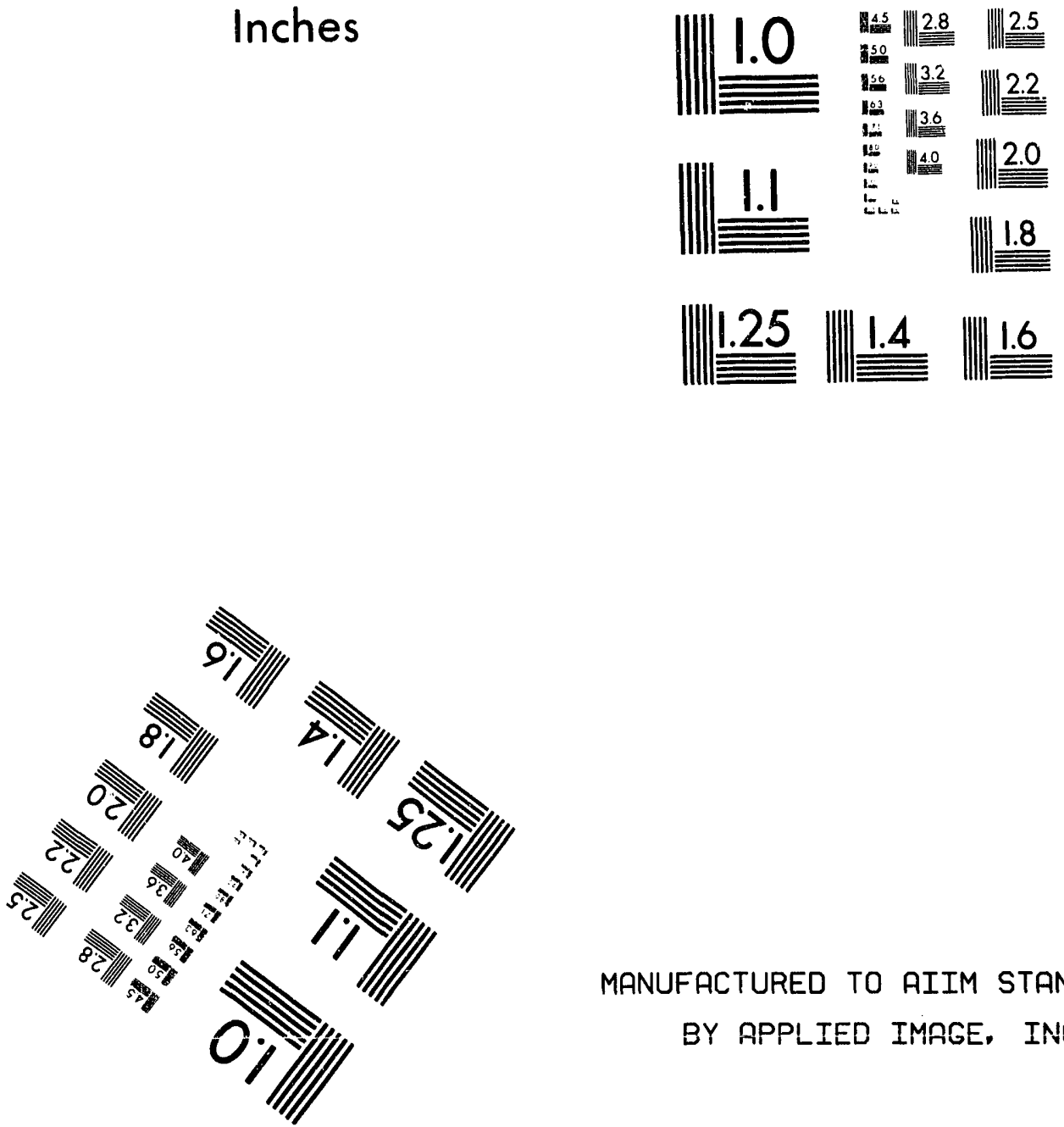

MANUFACTURED TO AIIM STANDARDS

BY APPLIED IMAGE, INC.

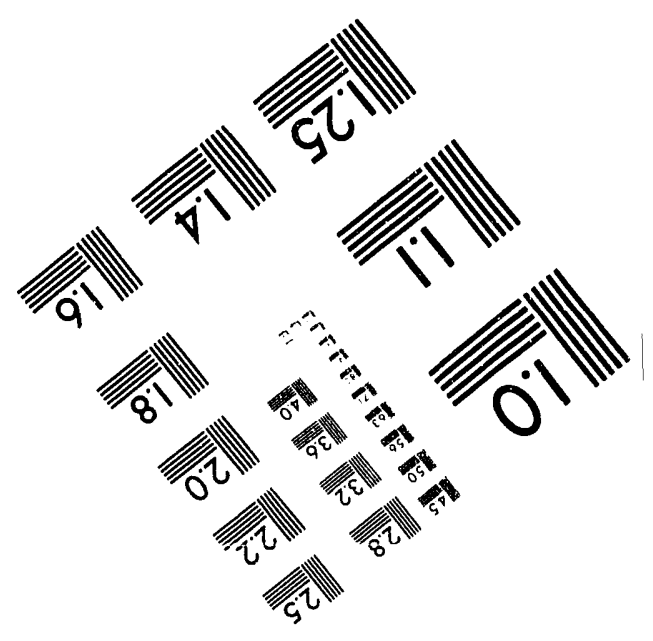



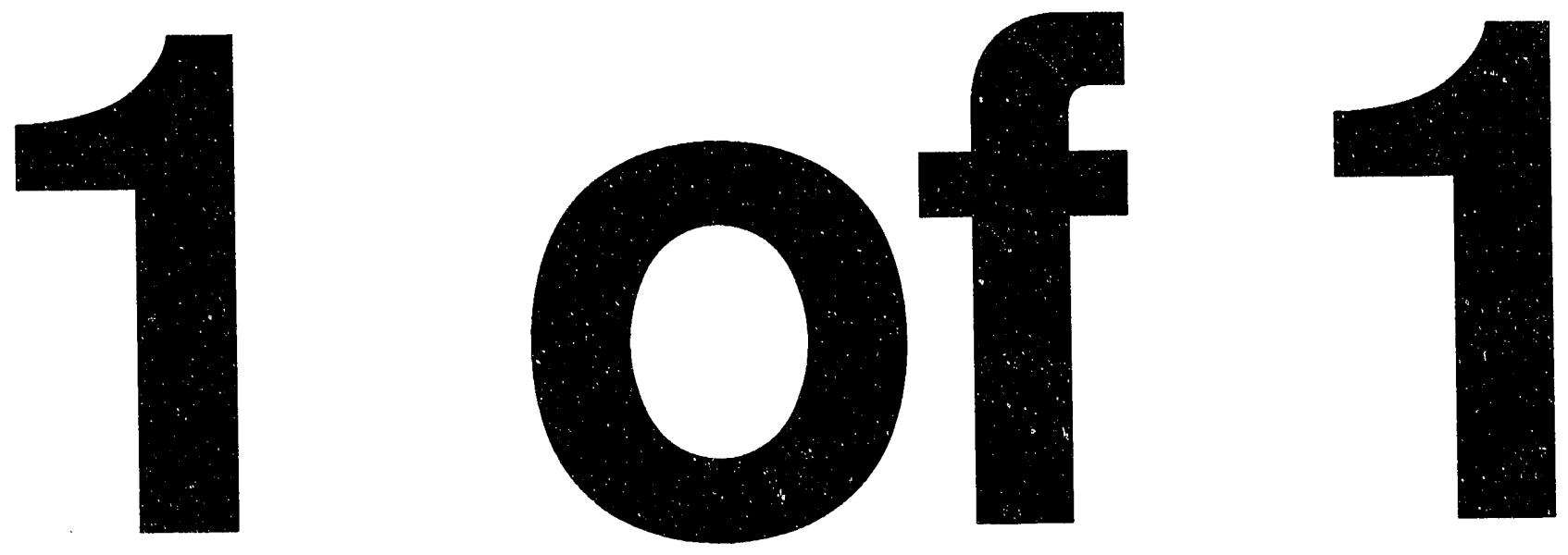


\title{
Math and Science School (MASS)
}

\section{A Department of Energy Enhancement Program to Benefit Students from Native American Tribes affected by the Hanford Reservation}

\section{Progress Report}

March 20, 1993

Prepared by

Michael Jaeger, Associate Professor of Education

Eastern Oregon State College

La Grande, OR 97850

503-962-3682
FECLVED

JUN 111993

OSTI

\begin{abstract}
Math and Science School is a program designed to enrich and encourage elementary students and teachers of the Confederated Tribes of the Umatilla Indian Reservation in the areas of mathematics and science activities. By providing access to special hands-on workshop sessions held in the mobile science laboratory at the school sites during the school year for students and teachers and with a separate summer inservice program for students, elementary children and teachers are encouraged to explore the fascination of science and the utility of mathematics through use of integrated curricula. The Department of Energy grant underwrites the instructional costs of this system while the grantee provides the mobile laboratory and the majority of the materials.
\end{abstract}

\section{Purpose of the Project}

Data compiled from the Tribe's children that describes academic achievement in science and mathematics is poor. Students perform poorly in elementary science and math. Grades, academic testing, and performance in junior and high school science and mathematics all show poor performance. The purpose of this project was to stimulate, encourage and to enrich the mathematics and science experiences of the Tribe's children by providing kid's workshops. The activities were designed to link both highly motivational hands-on activities in physical and life science, but also to offer cultural links to issues, stories, and natural resources appropriate to the Tribe's problems, cultural heritage, and environment.

In conjunction with student workshops, the companion purpose of the grant is to acquaint teachers of the tribe's students with techniques, skills and abilities in the teaching of mathematics and science. Workshops held during and after the school day were planned to help teachers engage students actively and to help them view science curriculum from a broader cultural perspective. 


\section{Progress Toward Objectives}

Two phases of the MASS project are supported by the grant, Phase I: School year program and Phase II: Summer Program. Formative evaluation of Phase I can only be addressed at this time.

\section{September}

To facilitate the enrichment/encouragement program within the schools of the Tribe's children, initial meetings were held with the various superintendents of Pendleton, Umatilla, Athena-Weston and Milton Freewater districts.

Early agreement and articulation between the Tribe, the Umatilla Education Service District, the participating School Districts and Eastern staff were made. Miriam Munck, Eastern's Science specialist hired specifically for the purpose of organizing and delivering Phase I of the project developed important relationships between the parties involved.

\section{October-November-December}

With help from school districts, Miriam developed a calendar of on-site visitations. An example of a schedule that she developed is given below:

November $2 \quad$ Washington Elementary

November 3 Washington Elementary

November $6 \quad$ Stanfield Elementary

November 10

November 12

November 16

November 17

November 18-19

December 3

December 4

December 7-9,15
Ferndale Elementary

Helix Elementary

Athena Weston

Athena Weston

North Powder

Milton Freewater

Ukiah

Washington Elementary
Students (Pull-out during the day, 4 sessions at 16 each) Teachers PM Students (Pull-out during the day, 4 sessions at 16 each)

Primary teachers

Teachers

Teachers

Primary Grades AM-

Intermediate Grades PM -Teacher

Student workshops

Teachers

Teacher workshops

Teacher Workshops

Student workshops

During this time, Miriam visited several school sites and offered workshops to both children and teachers alike. The usual method was to take small groups of children during the day to do projects and activities using the AIMS curriculum. After several waves of children experienced the mobile science laboratory, Mirimam prepared for the afternoon workshops with the teachers.

January-March

Miriam reports that after some initial difficulties in articulating times and logistics with 
some district personnel and teachers, that a system has been developed for inservicing students and teachers that reduces the amount of interference to the school day and calendar.

Workshops are varied, but have focused on Native American stories and their scientific/mathematical adjunct. Miriam is careful to collect attitudes about science from students using a standardized instrument. Further, anecdotal and videographic data is planned for election during the spring months.

An aggressive schedule of workshops is planned for April and May.

\section{Summary}

Initial responses from participants, teachers, district personnel and the Tribe's representatives are positive. Summative evaluation of the project will be prepared at the end of Phase II sometime in September of 1993.

Fiscally, we have been able to weave the last year of the NSF enhancement grant with the DOE grant. This has allowed us to use substitute time, materials costs, transportation and other costs and extend our capabilities with the DOE funds. Miriam has been able to do far more because of the collaboration of grant funds. The facility of the mobile science laboratory and the ready access of curriculum and materials has facilitated the operation of the grant.

Summer plans are now in the working. Staff hires are the primary chore with two faculty being sought as summer workshop leaders.

\section{DISCLAIMER}

\footnotetext{
This report was prepared as an account of work sponsored by an agency of the United States Government. Neither the United States Government nor any agency thereof, nor any of their employees, makes any warranty, express or implied, or assumes any legal liability or responsibility for the accuracy, completeness, or usefulness of any information, apparatus, product, or process disclosed, or represents that its use would not infringe privately owned rights. Reference herein to any specific commercial product, process, or service by trade name, trademark, manufacturer, or otherwise does not necessarily constitute or imply its endorsement, recommendation, or favoring by the United States Government or any agency thereof. The views and opinions of authors expressed herein do not necessarily state or reflect those of the United States Government or any agency thereof.
} 

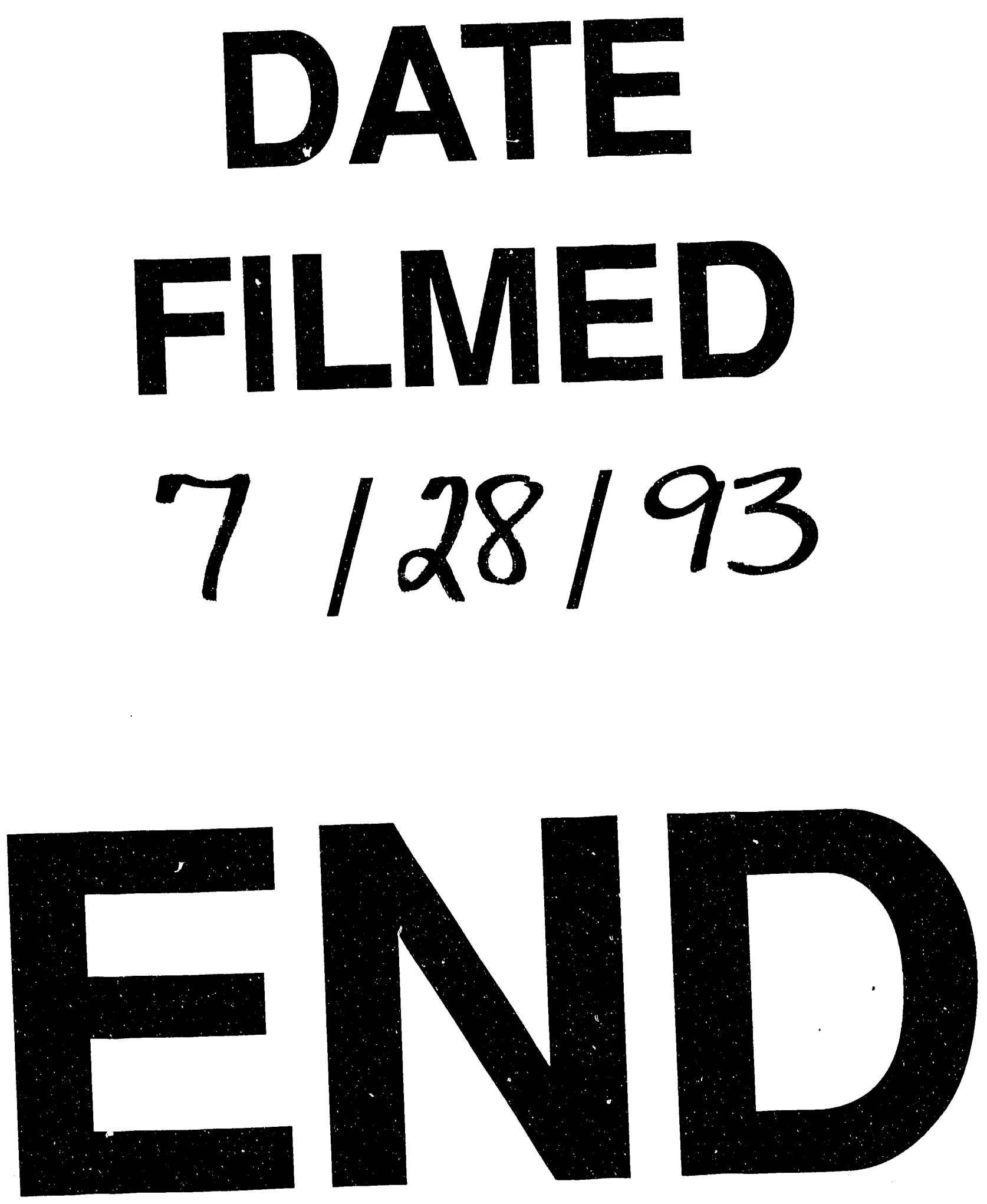
